\title{
Nepal's Economic Growth in the Context of Absorption, Trade Imbalance and the Fixed Exchange Rate
}

\author{
Tula Raj Basyal \\ Former Executive Director, Nepal Rastra Bank, Research Department, and Former \\ Senior Economic Advisor, Government of Nepal, Ministry of Finance \\ Email: tbasyal@bus.Illinois.edu
}

\section{Economy Facing Rising Uncertainty}

High consumption in Nepal has not supported economic growth. Rather, it has deteriorated the trade imbalance and, during the recent two fiscal years, even generated the balance of payments (BOP) deficit. Persistence of large macroeconomic imbalances has generated unfavorable impacts on the financial system as well. Policy failure in addressing the unrelenting inflationary situation has not only reduced the incentive for financial saving but also made the people's living conditions harsh. Discriminatory legal and regulatory arrangements have fostered dualities in the financial system as they have decreased attractions and increased risks for the financial institutions that fall under tighter regulatory regime. To cite the specific case in point, parallel legal and regulatory regimes between the financial institutions licensed by the central bank and those by the Department of Cooperatives have produced dualities and distortions in the financial market and increased vulnerabilities in the financial system regulated by the central bank. This has resulted in a peculiar situation where two sets of players follow two different sets of rules coming through the two respective umpires although the game and ground remained the same. Rents created by regulatory fragmentation have discriminated against the tightly regulated set of players. Equally surprising on the part of the tighter referee has been its apparent lack of necessary attention and the timely action, thereby letting the problem of the lack of a level playing field for all the financial players to continue. Such a paradox could grievously hurt the objective of building and sustaining a sound, stable, efficient and strong financial system. At the same time, the presence of the adverse investment climate especially attributed to the policy instability, inappropriate policy stance, hostile non-economic environment, and government inaction has robbed the economy of the prospective favorable outcomes that the prudent financial system in general and the robust banking sector in particular could have delivered for Nepal. The trends of declining exports and surging imports resulting in large trade imbalances in the face of modest economic growth and double-digit inflation have exposed the structural vulnerabilities of the Nepalese macro economy and undermined the goals of Nepal's economic transformation.

\section{Slow Economic Growth in the New Millennium}

The economic growth performance of Nepal has not only remained slow but, in relation to the level of investment in the economy, also modest. It may be worth mentioning that, for attaining economic development objectives in an environment of smooth and stable macro economy, saving and investment should remain high and investments must be productive. Wide gap between exports and imports 
should be substantially narrowed. Toward these ends, excessive consumption and unnecessary imports should be discouraged. Sound framework and incentives should be built to ensure that the resources are productively utilized. The government policies and arrangements should help ensure such a framework However, the economic growth (as measured by the producer prices) during the past decade (FY 2001/02- FY 2010/11) could average an annual rate of 3.7 percent (data source: Central Bureau of Statistics, website http://www.cbs.gov.np). With the population growth estimate at 2.2 percent, Nepal's per capita income growth during the decade could average 1.7 percent only. In an underdeveloped country like Nepal where development goals have been unmet and the challenges of poverty and income inequality have remained daunting, such a modest performance in the per output growth would signal deeper problems confronting the economic development performance and process of the country. What is further worrisome is that the resources being invested in the economy have not remained productive as they have not contributed to economic growth to the extent projected.

\section{Unfavorable Investment Climate and Galloping Trade Deficit}

During the decade observed, the growth in absorption (defined as the total of consumption and investment) could not contribute to economic growth, as desired, due to rising imbalances in the goods and services trade. During the decade, the annual average growth rate of government consumption exceeded the growth rate of private consumption while the growth rate of capital formation in the government compared to that in the private remained slightly lower. The average annual growth rates during the decade were total consumption 5.3 percent (government 6.8 percent and private 5.1 percent), gross fixed capital formation (GFCF) 2.0 percent (government 1.9 percent and private 2.0 percent, investment (GFCF plus change in inventories) 4.5 percent, and absorption 5.1 percent (calculations based on the national accounts data provided in the CBS website). The economic growth rate (3.7 percent) remained below the growth rate of absorption (5.1 percent) because the net exports of goods and services (trade deficit) grew by 13.6 percent (exports minus 3.8 percent, of which goods minus 6.0 percent and services 0.1 percent, and imports 4.9 percent, of which goods 5.0 percent and services 3.9 percent). The annual average growth of deficit in the goods trade rose by 11.6 percent while the surplus in the services trade fell from Rs. 9.3 billion in $2001 / 02$ to Rs. 175.0 million in 2010/11, with the services trade balance also experiencing deficits during 2005/06 through 2008/09. The volatility and the overall declining trend in the goods export as well as the declining surplus and emerging deficit in the services trade remained a major hurdle in strengthening the trade sector and contributing positively to the economic growth of Nepal. Various shocks like the unfavorable clauses in the trade treaty of 2002, non-compliance of some of its provisions, abolition of general system of trade preferences since January 1, 2005, infrastructural bottlenecks, less priority accorded to the growth of export sector, policy regime favoring investment in the non-tradables instead of the tradables, and reduced tourism receipts contributed to exacerbate the situation of trade deficits. The following indicators will further corroborate this observation. 


\section{Despite High Absorption, Low Economic Growth due to Large Trade Deficit}

As percent of gross domestic product (GDP), total consumption rose from 88.3 percent in FY 2000/01 to 102.4 percent in FY 2010/11. Accordingly, the gross domestic saving (GDS) as percent of GDP fell from 11.7 percent in FY 2000/01 to a minus 2.4 percent in FY 2010/11. This signaled that consumption exceeded the GDP, a situation that reflected excess of trade deficit over the absorption in the economy. This fact evidences the weakest situation of Nepal's external competitive strength. This urgently warrants vigorous efforts toward improving the production and productivity levels of the economy. While the government consumption/GDP ratio increased from 8.1 percent in FY 2000/01 to 10.8 percent in FY 2010/11, the private consumption ratio jumped from 80.2 percent in the former year to 90.0 percent in the latter. Between FY 2000/01 and FY 2010/11, investments (GFCF plus change in inventories) increased from 22.3 percent to 24.0 percent. However, the GFCF between these two years saw a significant decline, from 19.2 percent to 16.2 percent. The government GFCF/GDP ratio declined from 4.1 percent in 2000/01 to 3.4 percent in 2010/11 while such ratio in the private sector fell more sharply, from 15.1 percent in 2000/01 to 12.8 percent in 2010/11. The past decade thus marked a gloomy performance with respect to fixed capital formation in both the government and the private sectors. The economic growth, employment, and other macroeconomic consequences of such weak state of fixed capital formation in the economy could be disastrous for a least developed country (LDC) like Nepal. With the rise in the absorption/GDP ratio from 110.6 percent in 2000/01 to 126.4 percent in 2010/11, the trade deficit/GDP ratio increased from 10.6 percent in FY 2000/01 to 26.4 percent in FY 2010/011, making it inevitable to encourage the exports and discourage the growth of imports intended for inessential consumption. For addressing the widening trade gap required creating incentives so that resources were switched from consumption and unproductive uses toward productive investments and export sector. Besides, fostering an investor-friendly environment remained crucial not only for increasing the foreign direct investment (FDI) but also for discouraging the possibility of capital flight.

In fact, the reduced incentive for investing in industrial enterprises in general and export-oriented industries and activities in particular has been the major factor for the surge in the imports-based consumption, which has not only deteriorated the domestic saving but also increased risks and vulnerabilities in the macroeconomic performance and stability. Greater allocation of resources for consumption at the cost of productive investments would reduce the productive base of the economy, thereby reducing its future growth potential. Measures like reducing consumption and increasing saving in addition to utilizing the available resources in sectors and activities that have the potential of transforming the production possibilities of the economy on a most productive and sustained basis would become of paramount importance even for successfully tapping the opportunities offered by the process of economic liberalization. So, the focus should be on decreasing incentive for excessive consumption and imports and increasing incentive for fostering saving and exports. Besides, the investment should become productive enough to raise economic growth, generate employment, optimally utilize domestic resources, and improve the competitive position of the economy. The private sector investment 
during the liberalization period of post-1990 increased substantially but was not as productive for the economy as anticipated due to a number of reasons. So, mere pronouncements of good policies would not be meaningful unless prerequisites and incentives for ensuring matching productive investments are ensured. Besides the role of policies, regulatory mechanisms and operating procedures in the fields of fiscal, monetary, foreign exchange, financial sector, capital markets, public debt management, foreign investment, etc., the policies, arrangements, mechanisms, and systems applicable in the industrial and commercial sectors of the economy would remain pivotal in raising productivity, increasing the competitive position of the economy, and making its long-term health sound. So, the stance and stability of commercial and industrial policies would be particularly important in raising confidence and trust among the investors and ensuring an investment climate that becomes instrumental for rapid economic growth and development of the country on a sustainable basis.

\section{Current Situation in Trade}

The BOP remained in the negative every consecutive month during FY 2009/10 and so far during FY 2010/11. The BUP deficits (Rs. billion) during the consecutive 12 months of FY 2009/10 were 1.42, 3.76, 19.45, 20.49, 19.60, 19.79, 21.8, 23.53, $22.10,17.36,15.07$, and 3.63 (annual) respectively. The annual BOP surplus in 2008/09 was Rs. 44.78 billion. All the years following FY 2001/02, where the BOP deficit had amounted to Rs.3.34 billion, had exhibited BOP surpluses. Prior to that, BOP deficits were registered in FY 1995/96, FY 1994/95, FY 1987/88, FY 1984/85, FY 1983/84, FY 1982/83, and FY 1974/75. Among others, large gold imports during 2009/10 contributed to increase the BOP deficit. The gold imports (Rs billion) during the 12 consecutive months of 2009/10 amounted to $1.39,7.89,14.92$, $19.26,25.55,33.61,35.47,37.47,37.89,39.41$, and 41.64 respectively. The total gold imports (Rs billion) for the entire 2006/07, 2007/08, and 2008/09 were 3.52, 3.75 , and 16.57 respectively. According to the available statistics, every month during the first eight months so far during FY 2010/11 has unfolded BOP deficit amounting to (in Rs. billion) $0.31,4.36,6.88,5.03,3.35,4.43,12.57$, and 11.30 respectively. The gold import during the eight months of 2010/11 was Rs. 2.63 billion in comparison to the import of Rs. 37.47 billion during the same period in 2009/10, implying that the BOP during 2011/12 also registered continuous deficit despite substantial reduction in the gold import The ratio of exports/imports during the first eight months of FY 2010/11 remained at 16.9 percent (India 16.7 and other countries 17.2) from the same period's ratios of 16.1 percent (India 18.9 percent and other countries 12.6 percent) in FY 2009/10, 24.9 percent (India 27.0 and other countries 22.3) in FY 2008/09, and 27.1 percent (India 29.1 and other countries 23.5) in FY 2007/08. In the total merchandise trade (exports and imports) during the first eight months of FY 2007/08, 2008/09, 2009/10, and 2010/11, imports represented 78.7 percent, 80.0 percent, 86.2 percent, and 85.5 percent respectively. There has occurred current account deficit since FY 2009/10. Along with the BOP deficit, the foreign exchange reserve during the first eight months of FY 2010/11 declined by 4.4 percent to an equivalent of 7.1 months' merchandise and service imports from a level of 10.0 months' in mid-July 2009. A sudden fall by an equivalent of 2.9 months' import capacity during the 20-month period demonstrates reduced external sector capacity of the economy. 
Due to domestic and external reasons, Nepal's external trade has gained comparatively less from the process of globalization. Among the South Asian economies, Nepal's external trade situation has remained the weakest. Among the five economies of South Asia (Bangladesh, India, Nepal, Pakistan, and Sri Lanka), ratios like the exports/GDP, exports/imports, and trade deficit/GDP have remained most unfavorable for Nepal. According to the World Bank's World Development Report 2010, Nepal's export/GDP ratio in 2008 was 8.7 percent compared to 12.1 percent in Pakistan, 14.7 percent in India, 19.5 percent in Bangladesh, and 20.6 percent in Sri Lanka. Exports/imports ratio in 2008 was 64.4 percent in Bangladesh, 61.4 percent in India, 59.8 percent in Sri Lanka, 48.1 percent in Pakistan, and 30.8 percent, the lowest such ratio, in Nepal. Trade deficit as percent of GDP was 9.2 in India, 10.7 in Bangladesh, 13 in Pakistan, 13.8 in Sri Lanka, and 19.6, the highest, in Nepal.

Efforts toward trade improvement have not produced satisfactory results. The Three-Year Interim Plan (TYIP, 2007/08-2009/10) had a target of increasing the volume of total exports (merchandise) from Rs. 59.40 billion in the base year (2006/07) to Rs. 100 billion by the final year of the TYIP (2009/10). Instead, exports only amounted to Rs. 59.27 billion in 2007/08, Rs. 67.70 billion in 2008/09, and Rs. 61.13 billion in 2009/10. The exports as percent of the GDP witnessed a downward trend, from 8.2 in 2006/07 to 7.3 in 2007/08, 6.9 in 2008/09, and 5.2 in 2009/10. The first eight months of 2010/11 saw an export volume of Rs. 42.84 billion, an increase of Rs. 2.66 billion from Rs. 40.18 billion recorded during this same period in 2009/10. Contrary to the TYIP target of reducing the merchandise trade deficit as percent of the GDP to 15 in 2009/10 from 18.6 in 2006/07, such ratios widened to 19.9 percent in 2007/08, 21.9 percent in 2008/09, and 27.1 percent in 2009/10. Even if the trade deficit amount remains constant at the previous year's level (Rs. 317.67 billion), the trade deficit/GDP ratio in 2010/11 is expected to record 23.6 percent. The TYIP visions and targets in the trade sector have thus been completely shattered. The trade situation with India seems to be deteriorating faster. For example, the export/import ratio with India fell to 25.2 percent in 2008/09 and 18.4 percent in 2009/10 from 36.0 percent in 2006/07, a fall of 17.6 percentage points during the three-year period. Such ratio for the rest of the countries was 21.9 percent in 2008/09 and 13.1 percent in 2009/10 from 22.4 percent in 2006/07, a fall of 9.3 percentage points during the same period. Trade with India, which accounted for 54.8 percent share in the total trade deficit of Nepal in 2006/07, saw this ratio rise to 56.0 percent both in 2008/09 and $2009 / 10$, with the shares of the rest of the countries in these two years at 45.2 percent and 44.0 percent respectively. During the first eight months of FY 2010/11, India's share in the total trade deficit was 67.7 percent, far higher than the ratio of 52.9 percent during the same period in FY 2009/10. So, any success in addressing the trade imbalance with India would be of substantial help toward correcting Nepal's overall trade imbalance.

What determines the competitiveness of exports? Exchange rate is a crucial variable determining the competitiveness of the export as well as the overall economy. However, in Nepal's trade with India, the subject more relevant than the exchange 
rate has been the stance, and implementation of, the trade agreements between the two countries. So, adoption of more liberal trade agreement favoring Nepalese exports in India and its undisturbed implementation would not only improve the adverse trade and BOP imbalances with India but would also avoid the need for adopting short-term trade-restrictive options in addition to enhancing Nepal's longterm capacity to import from India. Exchange rate has become less sensitive in determining Nepal's trade balance with India because of the similar trends of the inflation rates of these two countries, hence not misaligning Nepal's real exchange rate with India. So, devaluing the Nepalese Currency (NC) vis-à-vis the Indian Currency (IC) would be a less effective measure for improving the external balance with India than ensuring a full-fledged implementation of a liberal trade treaty with India. Encouraging export-oriented FDI from India would constitute a supplementary measure in this respect.

\section{Nepal's Exchange Rate}

Nepal maintains a unique exchange rate arrangement whereby the exchange rate with India has been fixed while that for the other currencies has been marketdetermined. Such an arrangement was necessitated to avoid the likely emergence of broken cross rates among the currencies as such broken rates could generate incentive for speculative tendencies in the exchange market and create disturbances in the healthy flow of trade transactions. Such fears become genuine due to the fact that India still controls the convertibility of the IC in the capital account, that the volume of Nepal's import trade with India in the IC still occupies a dominant share (81.3 percent of the merchandise imports from India during the first eight months of 2010/11 was in IC and the rest 18.7 percent in the US dollars), and that there are open borders and close trade relationships with India.

The exchange rate of the NC with the IC has remained fixed since 1960 while flexible exchange rate exists with the rest of the currencies the rates of which are quoted daily. To maintain the exchange rate at its predetermined level, the monetary authority (in Nepal, the Nepal Rastra Bank--NRB) stands ready to buy or sell foreign exchange at the specified rates. Thus, the fixed exchange rate (FER) serves as the nominal anchor or intermediate target of monetary policy. The current exchange rate of Rs. 1.60 per unit of IC has been in operation since February 12, 1993. In comparison, the exchange rate with the US dollar depreciated from Rs. 45.65 a dollar in 1993 to Rs. 72.20 a dollar now (May 17, 2011), representing 36.8 percent decline in the value of the NC over the 18 years and an average annual depreciation of 2.6 percent. Nepal presently quotes buying and selling rates for 16 currencies and only the buying rates for three currencies.

Because of the FER with the IC and flexible arrangements with the other currencies, some observers feel that the exchange rates between the IC and other currencies are not judiciously treated and appropriately maintained. They are particularly concerned about the persistent imbalances in the external sector, especially the huge merchandise trade deficit that Nepal has been experiencing for decades. Their apprehension being that the IC has been given special favour relative to the other currencies since the exchange rate regime in operation has made the other countries' products costlier and the Indian products cheaper in Nepal. By the same 
token, the Nepalese products have been made costlier in India, resulting in larger trade deficit with India. Observers also opine that Nepal's exchange rate system has undermined the monetary independence and effectiveness in the process of attaining the monetary policy goals. They believe that the monetary policy should be designed in a way that helps enhance its dynamic role in the economy, especially contributing to macroeconomic stability and prudence in an environment of sustained high economic growth.

\section{Fixed Exchange Rates at the Global Level}

Though the current global trend has been toward adopting more flexible exchange rate arrangement, 44 countries including Nepal have pursued a conventional peg (Report on Exchange Arrangements and Exchange Restrictions, 2010, IMF). Those pegging to the US dollar are Aruba, Bahamas, Bahrain, Barbados, Belize, Bolivia, Eritrea, Jordan, Maldives, Netherlands Antilles, Oman, Qatar, Saudi Arabia, Turkmenistan, UAE, and Venezuela. Those pegging to the Euro are Cape Verde, Comoros, Denmark, Latvia, Sao Tome and Principe, West African Economic and Monetary Union (WAEMU) countries (Benin, Burkina Faso, Cote d'Ivoire, GuineaBissau, Mali, Niger, Senegal, and Togo), and Central African Economic and Monetary Community (CAEMC) countries (Cameroon, Central African Republic, Republic of Congo, Equatorial Guinea, and Gabon). Those pegging to the composite currencies are Fiji, Kuwait, Libya, Morocco, and Samoa. Countries pegging to other currencies are Bhutan (Indian rupee at par), Lesotho, Namibia, and Swaziland (South African rand at par), and Nepal (Indian rupee at Rs. 1.60). According to the IMF Report, 2010, no country in South Asia has so far adopted free floating regime while Afghanistan, India, and Pakistan have adopted the floating regime with the monetary policy framework being the monetary aggregate target in Afghanistan. The monetary policy framework in India and Pakistan has been categorized as the "other" where there is no explicitly stated nominal anchor but the authorities rather monitor various indicators in conducting the monetary policy. Bhutan, Nepal, and the Maldives have adopted the conventional peg, with the monetary policy framework being classified as the exchange rate anchor. The US dollar has served as the exchange rate anchor in the Maldives while such anchor for Bhutan and Nepal has been classified as the other. The exchange rate arrangement in Bangladesh and Sri Lanka has been termed as the stabilized arrangement, with the monetary policy framework being the exchange rate anchor (in US dollar). However, the de jure exchange rate arrangement in Afghanistan, Bangladesh, India, Maldives, Pakistan, and Sri Lanka has been mentioned as floating. No country in South Asia has adopted the capital account convertibility.

\section{Nepal's Policy Developments}

Among Nepal's important policy developments over the years in the financial, trade and monetary fields have been the adoption of liberal licensing policy and marketdetermined interest rate regime for the banks and financial institutions, focus on prudential regulation and risk-based supervisory framework, convertibility of the NC in the current account transactions, and adoption of the auction-based open market operation (OMO) for the purpose of liquidity management. In the context of maintaining the FER with the IC, what has been experienced in the recent years is the chronic shortfall of the IC resulting from the large BOP deficits with India. To 
supplement the IC reserve, huge amount of IC is being purchased by selling dollars. Such dollar sale amounted to US\$930 million in FY 2006/07, US\$1.73 billion in FY 2007/08, US\$ 1.52 billion in FY 2008/09, US\$ 2.19 in FY 2009/10, and US\$ 1.22 billion during the first eight months of 2010/11 equivalent to IC 40.3 billion, 70.6 billion, 73.4 billion, 102.1 billion, and 55.6 billion respectively. In addition, Nepal has been importing from India a large volume of intermediate goods through dollar payments which, in NC equivalents, amounted to 17.7 billion in FY 2006/07, 32.0 billion in FY 2007/08, 33.1 billion in FY 2008/09, 47.7 billion in 2009/10, and 22.0 during the first eight months of FY 2010/11. Nepal has been able to do this due to large foreign exchange earnings mainly attributed to the remittance inflows.

\section{IMF Assessment}

According to the 2008 Article IV Consultations Report of the IMF for Nepal, the peg provides a highly credible, simple, predictable, and transparent nominal anchor. The peg helps in keeping business uncertainty and transactions costs low. The peg has been instrumental in anchoring inflation over the last several years. However, the growing productivity differential between India and Nepal could require the adoption of other more flexible regimes, including a basket peg, which could help smooth domestic adjustment to a possible further appreciation of the IC.

The IMF Staff Statement at the Conclusion of the 2010 Article IV Discussions with Nepal on March 8, 2010 noted that macroeconomic stability had been maintained in past years, but the global crisis was having a delayed impact on Nepal's economy and exposing its structural weaknesses. The exchange rate peg and prudent fiscal policies were highlighted as anchors of stability. High remittances resulted in rising foreign exchange reserves despite lackluster export performance. Recently, however, international reserves declined significantly due to a slowdown in remittance growth and accelerating imports. The reserves situation was assessed as fragile. With weaker remittances and exports contracting, the current account was projected to shift into a significant deficit. The Statement also observed that the peg should remain the key macroeconomic policy priority, and monetary policy was required to be made fully consistent with this objective. Interest rates needed to be maintained above those prevailing in India. While the benefits of the peg were thus highlighted, it was also stated that the advantages of a floating regime were fairly limited in Nepal at the moment. While the floating regime provided some monetary policy autonomy and flexibility in responding to external shocks, a successful floating rate regime would require extensive institutional and operational foundations and frameworks that seemed to be extremely difficult to be developed and maintained sooner.

\section{Rapid Credit Facility}

The latest IMF Facility (Rapid Credit Facility-RCF) for Nepal also supported the exchange rate peg. The IMF's Executive Board had approved on May 28, 2010 for immediate disbursement an amount equivalent to SDR 28.52 million (about US\$ 42.05 million) to help address the economic impact of the global economic crisis that Nepal had been hit hard, albeit with some time lag, by the recent global economic downturn, the IMF's press release in this respect stated. The IMF observed that Nepal had been experiencing a significant decline in exports, a sharp 
slowdown in remittances and a worsening of economic confidence, which contributed to a large deterioration in the current account balance and a decline in international reserves besides the emergence of liquidity crunch in the banking sector. The RCF for Nepal aimed at addressing external and financial risks and helping catalyze possible donor support. The RCF, which provides a rapid and flexible financial assistance for low-income countries that faced an urgent BOP need, does not require any explicit program-based conditionality or review, but economic policies are expected to address the underlying BOP difficulties and support policy objectives including macroeconomic stability and poverty reduction. Financing under the RCF carries a zero interest rate, has a grace period of $51 / 2$ years, and a final maturity of 10 years.

According to the IMF, the external shock exposed Nepal's structural weaknesses, its reliance on remittances, and the build-up of risks in the financial sector. So, the government's policy program, supported by the IMF, is aimed at addressing these risks and stabilizing international reserves. At the core of the program are a tight monetary and fiscal policy stance to support the exchange rate peg, which remains Nepal's anchor for macroeconomic stability, and efforts to improve financial sector soundness

According to the IMF, the NRB has taken steps to tighten monetary policy through, inter alia, raising the Standing Liquidity Facility (SLF) rate. Building on a strong track record of fiscal prudence, including during the political transition, the government committed in the $2010 / 11$ budget to maintaining the domestically financed budget deficit close to 2 percent of GDP. The authorities introduced macro prudential measures to limit banks' liquidity risk and exposure to the real estate sector, and imposed a partial bank licensing moratorium. They are also committed to strengthening supervision, enhancing contingency planning, encouraging financial sector consolidation, and reforming the two State-owned banks. The authorities' program was stated as strong and well- focused. If fully implemented and provided that the external situation improved as envisaged, it was expected to restore Nepal's macroeconomic stability and lay more favorable conditions for higher growth and poverty reduction. This program could also serve as a bridge to a successor Fund arrangement, which would help address the country's structural challenges, the IMF notes.

\section{Real Exchange Rates}

Exchange rates are distinguished as the nominal and the real exchange rates. The nominal exchange rate is the relative price of the currency of two countries. For example, the IC $1=$ NR 1.60 could be expressed also as NC $1=$ IC 0.625 . An Indian who wants to obtain NC would pay IC 0.625 for each NC sought. A Nepalese who wants to obtain IC would get IC 0.625 for each NC that is exchanged. This common notion of the exchange rate is invariably the nominal exchange rate.

The real exchange rate of the currency is the relative price of the goods of two countries. That is, the real exchange rate tells us the rate at which we can trade the goods of one country for the goods of another country. The real exchange rate is sometimes called the terms of trade. A fall in the value of the domestic currency is 
called depreciation while a rise in the exchange rate is called an appreciation. For example, if IC $1=N C 1.70$ (a rise from IC $1=N C 1.60$ ), then NC 1 would be equivalent to IC 0.5882 compared to IC 0.625 before, reflecting a fall in the value of the NC by 5.9 percent. This is called the depreciation of the NC. On the other hand, if IC $1=\mathrm{NC} 1.50$ ( $\mathrm{a}$ fall from IC $1=\mathrm{NC} 1.60$ ), then NC 1 would be equivalent to IC 0.6667 compared to IC 0.625 before, reflecting a rise in the value of the NC by 6.7 percent. This is called the appreciation of the NC. It is a simple knowledge that the rate at which we exchange Indian and Nepalese goods depends on the prices of the goods in the local currencies and on the rate at which the currencies are exchanged. Given the FER between the NC and the IC, the rate at which we exchange the goods between the two countries would depend on the prices of the goods in the Nepalese and Indian markets in the respective currencies. The real exchange rate (RER) would be equal to nominal exchange rate (NER) multiplied by price of Nepalese good divided by price of Indian good. If the price of Nepalese good becomes costlier vis-à-vis the price of the Indian good, the RER of the NC would be higher. In other words, if the price of Indian good becomes costlier than the price of Nepalese good, the RER of the NC would be lower. The calculation of the RER for a single good suggests how we should define the RER for a broader basket of goods.

Real Exchange Rate $=$ Nominal Exchange Rate (the number of foreign currency units per domestic currency unit) $\times$ Ratio of Price Levels.

or, $\varepsilon=\mathrm{e} \times\left(\mathrm{p} / \mathrm{p}^{*}\right)$,

Where, $\mathrm{p}=$ Price of Domestic Goods (price level in the domestic country), and $\mathrm{p}^{*}=$ Price of Foreign Goods (price level in the foreign country).

As already stated, the RER between two countries is computed from the NER and the price levels in the two countries. If the RER is high (appreciation), foreign goods are relatively cheap and domestic goods are relatively expensive. If the RER is low (depreciation), foreign goods are relatively expensive and domestic goods are relatively cheap. With e constant, exchange rate will be appreciated when $p$ is greater than $p^{*}$. With e constant, exchange rate will be depreciated when $p^{*}$ is greater than $\mathrm{p}$.

According to the calculations based on the data forum of the World Economic Outlook, April 2011, the consumer-price-based inflation in Nepal during the last three decades (1980-2010) averaged 8.6 percent compared to 8.1 percent in India. According to the above method, the NC vis-à-vis the IC thus appreciated by 0.5 percent during the period. Though the nominal exchange rate was NC $1=$ IC 0.625 or IC $1=\mathrm{NC} 1.60$, the real exchange rate of NC on the basis of this inflation differential would then increase to NC $1=$ IC 0.6279 or IC $1=$ NC 1.5926 or 1.59 , reflecting a 0.6 percent depreciation of the IC vis-à-vis the NC, making Indian goods cheaper by 0.5 percent in Nepal or Nepalese goods costlier by 0.6 percent in India. So, to make the exchange rate neutral, the exchange rate of NC 1 would then have to be at IC 0.6221 in comparison to the previous rate of NC $1=\mathrm{IC} 0.625$. The corresponding nominal exchange rate would then be IC $1=\mathrm{NC} 1.6075$ or 0.61 . 
Likewise, the GDP price deflator-based inflation during the three decades averaged 8.9 percent in Nepal in comparison to a rate of 7.4 percent in India, resulting in the real exchange rate of NC at IC 0.6337 , a 1.4 percent appreciation of the NC. To neutralize the appreciation, the new nominal exchange rate should be IC $1=\mathrm{NC}$ 0.6164 , which gives the exchange rate of IC $1=$ NC 1.6223 or 1.62 . So, the required depreciation rate on the basis of the GDP deflator-based inflation would be higher.

\section{Conclusion}

The trends of declining exports and surging imports resulting in large trade imbalances in the face of modest economic growth and double-digit inflation have exposed the structural vulnerabilities of the Nepalese macro economy and undermined the goals of Nepal's economic transformation. So, allocating more resources toward productive pursuits and exports instead of toward consumption and imports would determine the pace and vibrancy of Nepal's economic growth momentum. The macroeconomic policy regime should be shaped and implemented with this consideration in mind. Since Nepal has pursued a FER regime with the IC and the real exchange rate of the NC with respect to the IC has increased only marginally, the stance and implementation of the trade agreements with India would be crucial for improving trade imbalance and facilitating the payments arrangements with India. No doubt, implementing the FER constitutes an important strategy toward supporting the price stability. However, the double-digit inflation that the Nepalese economy has been experiencing for the last three years raised challenges toward attaining the objective of price stability. To make the FER sustainable, there is the need to keep the domestic absorption (aggregate of consumption and investment), especially the consumption, at a manageable level besides pursuing other measures aimed at improving the productivity level and competitive position of the economy, through reducing the transaction costs, fostering productive investments and raising the availability of essential infrastructure services. While a widening productivity gap with India could present some challenges over time for exchange rate management, the present has not been considered as the opportune time to consider changing the rate or regime. Any marginal benefits of a move toward further flexibility could be outweighed by the costs of a regime change, especially in the prevailing environment of political and economic transition. Besides, there would emerge associated institutional and operational constraints of structural nature. In the ranking of Doing BusinessMeasuring Business Regulations, Nepal's position vis-à-vis India is lower among the variables like employing workers, getting credit, protecting investors, trading across borders, and closing a business, which, therefore, need to be improved for avoiding likely misalignment of Nepal's competitiveness position. Price stability especially at a level consistent with that in India would help in maintaining the competitiveness of the Nepalese economy through controlling the unnecessary appreciation of the NC. Given the similar price trends in Nepal and India, there has only been a small appreciation of the NC, implying that the exchange rate has not been a critical factor in determining the trade balance in Nepal. To correct the large trade imbalance and make the payments arrangements with India smooth and sustainable, there was the need for adopting a more liberal trade agreement that would favour Nepal and implementing the provisions of the agreement with 
commitment and credibility. Besides, the foregoing analysis shows that the significance of the full-fledged implementation of a liberal trade agreement that supports growth of Nepal's export sector is quite high. At the same time, striving to reduce inflation below the Indian inflation would definitely contribute to maintain Nepal's trade competitiveness. Similar would be the recommendation for improving the trade imbalances with the rest of the world.

\section{REFERENCES}

Basyal, Tula Raj. 2010, Nepal's Exchange Rate and Balance of Payments with India (Development and Trade Vol. 2, No. 2, Issue 4, March/April 2010), Ministry of Commerce and Supplies, Kathmandu, Nepal

Basyal, Tula Raj. 2010. Trade Imbalances with India and Exchange Rate (in Nepali). Karobar (National Nepali Daily), January 4, 2010, Kathmandu, Nepal

Basyal, Tula Raj. 2009, Addressing Large Trade Imbalances, Unproductive Investments, and High Consumption for Raising Competitiveness of the Nepalese Economy (Development and Trade, Vol. 2, No. 1, Issue 3, November 2009), Ministry of Commerce and Supplies, Kathmandu, Nepal

Basyal, Tula Raj, Nepalese Economy in the New Millennium-Trade Imbalances and Slow Growth, The Rising Nepal (National English Daily), October 28, 2009

Basyal, Tula Raj, Nepal's Exchange Rate Regime-Some Comments, The Rising Nepal (National English Daily), May 15, 2009, Kathmandu, Nepal

Basyal, Tula Raj, The Dutch Disease, The Kathmandu Post (National English Daily), September 21, 2009 Kathmandu, Nepal

Basyal, Tula Raj, Fixed Exchange Rate Regime in Nepal (Rajaswa: The Nepalese Journal of Public Finance and Development, Year 30, Volume 1), Ministry of Finance, Lalitpur, Nepal, May/June 2009

Gillis, Malcolm, Economics of Development, W. W. Norton \& Company, 1996, New York, USA

Ministry of Finance (MOF), Economic Survey 2010, July 2010, Kathmandu, Nepal,

National Planning Commission (NPC), Three-Year Interim Plan (2007-10), December 2007, Kathmandu, Nepal

International Finance Corporation, Doing Business 2010 (South Asia), Washington, DC, USA

International Monetary Fund (IMF), Annual Report on Exchange Arrangements and Exchange Restrictions 2010, Washington, DC, USA

International Monetary Fund, Article IV Consultations Report of the IMF for Nepal, 2008; IMF Staff Statement at the Conclusion of the 2010 Article IV Discussions with Nepal, Press Release on the Approval of the Rapid Credit Facility for Nepal, May 28, 2010, and World Economic Outlook, April 2011

Mankiw, N. Gregory, Macroeconomics, Worth Publishers, 1994, New York, USA

Nepal Rastra Bank, Recent Macroeconomic Situation (annual data for FY 2008/09 and FY 2009/10, and those for the first eight months of 2010/11), Kathmandu, Nepal

World Bank, World Development Report 2010, Washington DC, USA

Websites: Central Bureau of Statistics, MOF, NRB, IMF, World Bank, etc. 